\title{
Current Status of Rice Breeding for Sheath Blight Resistance
}

\author{
Susmita Dey $^{1 *}$, Jyothi Badri ${ }^{2}$, Khushi Ram ${ }^{1}$, A.K. Chhabra ${ }^{1}$ and D.K. Janghel ${ }^{1}$ \\ ${ }^{1}$ Department of Genetics \& Plant Breeding, Chaudhary Charan Singh Haryana Agricultural \\ University, Hisar, Haryana (125004), India \\ ${ }^{2}$ Indian Institute of Rice Research, Rajendranagar (500030) Hyderabad, India \\ *Corresponding author
}

Keywords

Rice, Sheath blight, Rhizoctonia solani, Resistance, QTLs

Article Info

Accepted:

04 January 2018

Available Online:

10 February 2019

\section{A B S T R A C T}

Rice is one of the three major food crops in the world. It is the staple food for most of the people of South-East Asia. Rice productivity fluctuates significantly from region to region; season to season due to biotic and abiotic stress. Sheath blight is one of the major biotic constraints in rice cultivation. It is caused by Rhizoctonia solani Kuhn. This disease can cause yield reduction between $20-50 \%$ depending on the severity of infection. Several genotypes reported for sheath blight resistance but none of the genotypes were found with absolute resistance. Sheath blight resistance is controlled by polygenes or quantitative trait loci (QTLs) each with small effect. Pyramiding of such QTLs is expected to increase resistance to sheath blight in the cultivars. Genetic engineering of crops with plant pathogenesis-related (PR) genes may give a promising and long-lasting solution for sheath blight disease management.

\section{Introduction}

Rice is one of the three major food crops in the world. It belongs to the genus Oryza and the tribe Oryzae of the family Gramineae (Poaceae). It is cultivating almost one fifth of the total land area covered under cereals. The United Nation declared '2004' as International Year of Rice. The year's theme "Rice is life" - reflects the importance of rice as a primary food source. It is the staple food crop for more than $60 \%$ of the global population. Rice provides $21 \%$ of global human per capita energy and $15 \%$ of per capita protein (IRRI 2002). Calories from rice are particularly important in Asia, especially among the poor, where it accounts for 50-
$80 \%$ of daily caloric intake (IRRI, 2001). It is estimated that around $90 \%$ and $91 \%$ of world's rice area and production respectively are present in Asia. But productivity of rice fluctuates significantly from region to region; season to season due to various biotic factors such as pest and diseases. The yield loss due to biotic stresses varies between $10-30 \%$ depending on severity. Rice is attacked by number of fungal, bacterial, viral and nematode diseases. Among all pathogenic organisms, fungal pathogens are limiting the rice productivity to a great extent. Blast, sheath blight and bacterial blight incidences have been reported from many rice growing areas of India. Sheath blight is one of the major biotic constraints occurring in most 
rice-producing areas. It is second in importance next to rice blast in reducing both grain yield and quality (Webster and Gunnell, 1992.

\section{Sheath blight disease}

Sheath blight disease caused by Rhizoctonia solani Kuhn. It survives either as sclerotia or mycelia in host plants' debris. Sclerotia can survive for 2 years in soil and spread during field preparation and flooding the field for irrigation (Webster and Gunnell, 1992; Brooks, 2007). During the infection process, the sclerotia germinate on rice sheaths forming infection cushions or appressoria. Then pathogen colonizes the entire plant through surface hyphae, developing new infection structures $(\mathrm{Ou}, 1985)$. According to Hashiba et al., (1982) secondary spread of disease depends exclusively on running hyphae that progress out from the initial lesions, from the lower part of the crop canopy towards its upper part along tillers and leaves, and across adjacent plant units (individual plants or hills). This has been commonly referred to as the 'vertical' and 'horizontal' spread process. The Canopy architecture and the associated microclimate have strong effects on both the mobilization of primary inoculum and the further spread of the disease (Savary et al., 1995). Canopy architecture depends on a number of factors like the crop establishment method (Willocquet et al., 2000), fertilizer input $(\mathrm{Cu}$ et al., 1996; Slaton et al., 2002; Tang et al., 2007), and the morphology of the rice genotype itself. Microclimate with high temperature $\left(28-32^{\circ} \mathrm{C}\right)$ and relative humidity (more than 90\%) facilitates the spread of this disease (Kaur et al., 2015).

At early stage disease symptoms appears as circular, oblong or ellipsoid, greenish-grey water-soaked spots about $1 \mathrm{~cm}$ long that occur on leaf sheath near the water level. Later these lesions enlarge and become oblong and irregular in outline, the center of which become grey white with brown margins. Due to the semi-saprophytic nature and uncharacterized pathogenicity mechanism of $R$. solani, it infects nearly 50 species besides rice. Earlier it was considering as minor disease of rice, but with the introduction of modern, semi dwarf nitrogen responsive cultivars it converted to major disease. Rice sheath blight can cause yield reduction between $20-50 \%$ depending on the severity of infection (Rao, 1995). In India, the estimation of losses due to this disease has been reported up to $54.3 \%$ (Chahal et al., 2003).

\section{Management of sheath blight}

Sheath blight disease management is very difficult due to its wide host range. There are different control measures available for sheath blight like host resistance, cultural control, chemical control and biological control. Among all these host resistance is most valid and eco-friendly choice for almost all type of plant stress.

\section{Host resistance}

Several groups have attempted to identify sources of sheath blight resistance by screening local accessions, cultivars, landraces, and/or advanced breeding lines. Sources of sheath blight resistance have been sought for different rice-growing regions by different research groups. These studies resulted in the identification of genotypes with moderate to high levels of resistance. Summary of important Sheath Blight resistance sources reported so far in literature is presented in Table 1.

Although several genotypes reported for sheath blight resistance but none of the genotypes were found with absolute resistance (Lee and Rush, 1983; Chen et al., 
2000; Eizenga et al., 2002; Jia et al., 2012; Dey et al., 2016) and their disease reaction is not consistent.

\section{QTLs associated with sheath blight}

Resistance to rice sheath blight is a complex, quantitative trait controlled by polygenes (Sha and Zhu., 1990; Li et al 1995; Pinson et al., 2005). First QTL linked to molecular marker RG118 identified by Li et al (1995) using $\mathrm{F}_{2-3}$ population of Lemont/Teqing. However, few researchers (Xie et al., 1992; Pan et al., 1999) proposed that sheath blight resistance in some rice varieties is controlled by only a few major genes. Over the past two decades, several sheath blight resistance quantitative trait loci (QTL) have been mapped and few of them are discussed here. Zou et al (2000) identified six QTLs $q S B-2, q S B-3, q S B-7$, $q S B-9-1, q S B-9-2$ and $q S B-11$, contributing to sheath blight resistance, located on chromosomes 2, 3, 7, 9 and 11 respectively, using $\mathrm{F}_{2}$ clonal population of Jasmine 85/Lemont. Sato et al (2004) also identified two QTLs for sheath blight resistance ( $q S B-3$ and $q S B-12$ ) on chromosomes 3 and 12 from the cross Hinohikari/WSS2//Hinohikari. $q S B$ $9^{T q}$, a major QTL derived from Teqing was reported by Zuo et al (2008). The QTL qSBR11-1 for sheath blight resistance was identified between the marker interval RM1233 (26.45 Mb) to sbq33 (28.35 Mb) on chromosome 11 from the population RILs of HP2216/Tetep (Channamallikarjuna et al., 2010)

Xu et al (2011) detected four QTL ( $q$ ShB1, $q S h B 2, q S h B 3$ and $q S h B 5)$ using a double haploid (DH) population of 'Maybelle. Zhu et al (2014) identified two major rice sheath blight resistance QTLs, $q S B 1-1^{H J X 74}$ and $q S B 11^{H J X 74}$ using chromosome segment substitution lines. Two major QTLs, qshb7.3 and $q s h b 9.2$ positioned on the chromosome 7 and 9 also identified using $\mathrm{BC}_{1} \mathrm{~F}_{2}$ mapping populations from the cross BPT5204/ARC10531 (Yadav et al., 2015). But so far, identified QTLs have not been utilized in development of sheath blight resistant cultivars and their breeding value has not been assessed. The reported QTLs for sheath blight resistance in rice are depicted in Table 2.

\section{Sheath blight breeding strategies}

Hypothetically sheath blight resistance may have two main groups of mechanisms viz., disease escape and physiological resistance (Sattari et al., 2014). Disease escape is strongly determined by crop architecture. Morphological traits like plant height (Li et al., 1995; Peng et al., 2003 and Willocquet $e t$ al., 2010), heading date (Shiobara et al., 2013; Li et al., 1995 and Park et al., 2008) \& stem thickness (Dey et al., 2016) positively correlated with sheath blight resistance. Sharma et al (2009) reported that the short stature at $s d-1$ semi-dwarfing locus was strongly linked to higher sheath blight infection. Physiological resistance correlated with physiological process that is associated with a decrease in efficiency of one or several of the infection stages of the pathogen.

As we discussed earlier sheath blight resistance is governed by quantitative traits, development of sheath blight resistant rice varieties is very difficult through traditional breeding method. Pyramiding of QTLs through marker-assisted selection may results stable and potential cultivars. Chen et al (2014) improved japonica rice resistance to sheath blight by pyramiding $q S B$ $9^{T Q}$ and $q S B-7^{T Q}$ on chromosomes 9 and 7 respectively. Zuo et al (2014) reported that NILs carrying both $T A C 1^{T Q}$ and $q S B$ $9^{T Q}$ showed more resistance than the NILs containing only one of them.

Further, there are evidences which show better disease management by pyramiding 
two or more disease resistance genes/QTLs. Singh et al (2012) developed multiple disease resistance basmati rice by transferring the blast resistance gene Pi54 and sheath blight resistance quantitative trait loci (QTL) from Tetep, qSBR11-1 to 'Improved Pusa Basmati'.

\section{Transgenic approach}

Development of transgenic rice plants may provide a novel strategy to reduce yield losses caused by sheath blight disease. Plant pathogenesis-related (PR) genes like PR-3 chitinase (Datta et al., 2000) and PR5(thaumatin-like protein) (Datta et al., 1999) provide resistance against sheath blight disease. Instead of single PR gene, combination of two PR genes shows more efficient for conferring a higher level of sheath blight resistance. Some example of PR combination are barley chitinase and barley $\mathrm{b}$ 1,3-glucanasegenes (Jach et al., 1995); maize ribosome inactivating gene MOD1 and rice basic chitinase gene RCH10 (Kim et al., 2003); CHI11and thaumatin-like protein (Kalpana et al., 2006); rice chitinase (CHI11) and tobacco b-1,3-glucanase(gluc) (Sridevi et $a l ., 2008)$; rice chitinase gene (OsCHI11) and the Arabidopsis NPR1 (AtNPR1) gene (Karmakar et al., 2017). ASD16 has been reported as stable transgenic line against Sheath blight (Rajesh et al., 2016). Shah et al (2009) reported that transgenic rice expressing an endochitinase gene (cht42) from Trichoderma virens showed up to $62 \%$ reduction in the sheath blight disease index.

Durable and broad-spectrum resistance cultivars can be obtained by the pyramiding of transgenes. Datta et al (2002) utilized Xa21 gene (resistance to bacterial blight), the $B t$ fusion gene (for insect resistance) and the chitinase gene (for tolerance of sheath blight) for gene pyramiding and identified stable elite rice lines resistant to disease and insect pests.
Maruthasalam et al (2007) reported that a transgenic Pusa Basmati1 line pyramided with chil1, tlp and Xa21 showed an enhanced resistance to both sheath blight and bacterial blight.

It is concluded that, rice sheath blight is second in importance next to rice blast in reducing both grain yield and quality. Germplasm with absolutely resistant to the pathogen have not been discovered till now. To reduce yield loss due to sheath blight, development of sheath blight resistant cultivars is important. However, only moderately resistant genotypes are reported.

These genotypes show variable disease reaction from one season to another season, which limit their use in breeding programme. Many QTLs for sheath blight resistance have been reported, but only few of them have been fine mapped. Validation of these QTLs is required before being used for markerassisted breeding (MAB).

It has been observed in several cases, resistance to sheath blight is a cumulative effect of several minor QTLs. Earlier efforts were focused on improvement of sheath blight resistance in elite susceptible cultivars. Employing genotypes possessing moderate resistance to sheath blight governed by minor effect QTLs in breeding programmes will only result in distribution of such QTLs in the segregating populations. Further, this also poses difficulty in retrieving the same phenotype in mapping populations as that of resistant parent phenotype making it difficult to establish marker-trait associations. Hence, breeding strategies have to be modified in the development of sheath blight resistant cultivars. Here, we propose a two step breeding strategy to deal with difficult and complex traits like sheath blight. 
Table.1 List of promising genotypes for sheath blight resistance

\begin{tabular}{|c|c|}
\hline (Local accessions/varieties/ cultivars/land races) & Reference \\
\hline NC 678, Dudsor, Bhasamanik & Das, 1970 \\
\hline $\begin{array}{l}\text { Chin-kou-tsan, Zenith, CO.17, Dinominga, Puang Nahk } \\
\text { 16, Baok, Toma-112, R.T.S.31, Kele Kala }\end{array}$ & $\mathrm{Wu}, 1971$ \\
\hline Lalsatkara & Roy, 1977 \\
\hline ARC15762, ARC 18119, ARC 18275, ARC 18545 & Bhaktavatsalam et al., 1978. \\
\hline $\begin{array}{l}\text { IR24, IR26, IR29, Jaya, Jaganath, Mashoori, Pankaj, } \\
\text { Rajeshwari, Supriya, Sabari, TKM6 }\end{array}$ & Rajan and Nair, 1979 \\
\hline $\begin{array}{l}\text { Nizersail, Rajasail, Tabend, Ta-poo-cho-z, Kattachambha, } \\
\text { DA 29, ARC 5925, ARC 5943, ARC 14529, ARC 10572, } \\
\text { ARC 10618, ARC10836 }\end{array}$ & Manian and Rao, 1979 \\
\hline Tapoochoz, Bahagia, Laka & Crill et al., 1982 \\
\hline Bharati, Rohini & $\begin{array}{l}\text { Gokulapulan and Nair, } \\
1983\end{array}$ \\
\hline Taraboli 1, Dholamula, Supkheru, Chidon & Borthakur and Addy, 1988 \\
\hline $\begin{array}{l}\text { BogII, Aduthurni, Chinese galendopuram, Arkavati, } \\
\text { Saket-4, Neela, MTU-3, MTU-7, MTU-13, MTU-3642, } \\
\text { BPT-6 }\end{array}$ & Ansari et al., 1989 \\
\hline Tetep, Tapoochoz, Guyanal & Sha and Zhu, 1990 \\
\hline LSBR-5, LSBR-33 & Xie et al., 1992 \\
\hline KK2, Dodan, IR40 and Camor & Singh and Dodan, 1995 \\
\hline RU8703196, B82-761 & $\begin{array}{l}\text { Marchetti et al., } 1995 \text { and } \\
\text { Marchetti et al., } 1996\end{array}$ \\
\hline $\begin{array}{l}\text { Chingdar, As 93-1, Panjasali, Up-52, Upland-2, Mairan, } \\
\text { N-22 and 1/69-70 }\end{array}$ & Singha and Borah, 2000 \\
\hline TIL 455, TIL 514, TIL 642 & Pinson et al., 2008 \\
\hline Jarjan, Nepal 555 and Nepal 8 & Shiobara et al., 2013 \\
\hline BPL 7-12, BML 27-1, BML 21-1 and Kajarahwa & Dubey et al., 2014 \\
\hline Tetep and ARC10531 & Yadav et al., 2015 \\
\hline $\begin{array}{l}\text { SM 801, 10-3, Ngnololasha, Wazuhophek, Gumdhan and } \\
\text { Phougak and RP 2068-18-3-5 }\end{array}$ & Dey et al., 2016 \\
\hline
\end{tabular}


Table.2 List of reported QTLs for sheath blight tolerance in rice

\begin{tabular}{|c|c|c|c|c|c|c|c|}
\hline $\begin{array}{l}\text { Chr. } \\
\text { no. }\end{array}$ & Locus & $\begin{array}{ll}\text { Marker } & \text { interval } \\
\text { or } & \text { Nearest } \\
\text { marker } & \\
\end{array}$ & $\begin{array}{l}\text { Resistant } \\
\text { parent }\end{array}$ & $\begin{array}{l}\text { Susceptible } \\
\text { parent }\end{array}$ & $\begin{array}{l}\text { Mapping } \\
\text { population }\end{array}$ & PV (\%) & Reference \\
\hline 3 & Qsbr3a & RG348-RG944 & Teqing & Lemont & $\mathrm{F}_{4}$ Bulk & 27.7 & \multirow[t]{2}{*}{ Li et al., 1995} \\
\hline 9 & Qsbr9a & RG910b-RZ777 & Teqing & Lemont & $\mathrm{F}_{4}$ Bulk & 9.4 & \\
\hline 2 & qSB-2 & $\begin{array}{l}\text { G243-RM29 } \\
\text { (RM29-RG171) }\end{array}$ & Jasmine 85 & Lemont & & $\begin{array}{l}14.4 \\
(21.2)\end{array}$ & \multirow[t]{6}{*}{ Zou et al., 2000} \\
\hline 3 & qSB-3 & $\mathrm{R} 250-\mathrm{C} 746$ & Jasmine 85 & Lemont & & 26.5 & \\
\hline 7 & qSB-7 & RG30-RG477 & Jasmine 85 & Lemont & & 22.2 & \\
\hline 9 & qSB-9-1 & C397-G103 & Jasmine 85 & Lemont & & 9.8 & \\
\hline 9 & qSB-9-2 & RG570-C356 & Jasmine 85 & Lemont & & 10.1 & \\
\hline 11 & qSB-11 & G44-RG118 & Jasmine 85 & Lemont & & 20.5 & \\
\hline 2 & qSBR-2 & RG171-G243A & Jingxi 17 & Zhaiyeqing 8 & $\mathrm{DH}$ & 11.2 & \multirow[t]{4}{*}{ Kunihiro et al., 2002} \\
\hline 3 & qSBR-3 & G249-G164 & Jingxi 17 & Zhaiyeqing 8 & $\mathrm{DH}$ & 10.5 & \\
\hline 7 & qSBR-7 & RG511-TCT122 & Jingxi 17 & Zhaiyeqing 8 & $\mathrm{DH}$ & 15.5 & \\
\hline 11 & qSBR-11 & CT244-CT44 & Jingxi 17 & Zhaiyeqing 8 & $\mathrm{DH}$ & 9.5 & \\
\hline 5 & qSB-5 & $\begin{array}{l}\text { C624-C246 } \\
\text { (C246-RM26) }\end{array}$ & Minghui 63 & Zhenshan 97B & RILs & $10.5(9.5)$ & \multirow[t]{2}{*}{ Han et al., 2002} \\
\hline 9 & qSB-9 & $\begin{array}{l}\text { C472-R2638 } \\
\text { (RM257- RM242) }\end{array}$ & Minghui 63 & Zhenshan 97B & RILs & $10.1(6.9)$ & \\
\hline 5 & Rsb1 & RFLP+SSR & 4011 & XZX19 & $\mathrm{F}_{2}$ & 11.2 & Che et al., 2003 \\
\hline 3 & qSB-3 & RM3856 & WSS2 & Hinohikari & $\mathrm{BC}_{1} \mathrm{~F}_{1}$ & 19.4 & Sato et al., 2004 \\
\hline 1 & qSB-1 & RG532x & Teqing & Lemont & RIL & 8 & \multirow{4}{*}{ Pinson et al., 2005} \\
\hline 2 & qSB-2 & C624x & Teqing & Lemont & RIL & 7 & \\
\hline 3 & qSB-3-1 & RG348x & Teqing & Lemont & RIL & 18 & \\
\hline 3 & qSB-3-2 & RZ474 & Teqing & Lemont & RIL & 10 & \\
\hline 4 & qSB-4-1 & RG1094c & Teqing & Lemont & RIL & 5.0 & \multirow[t]{3}{*}{ Pinson et al., 2005} \\
\hline 4 & qSB-4-2 & RZ590x & Teqing & Lemont & RIL & 7.0 & \\
\hline 5 & qSB-5 & Y1049 & Teqing & Lemont & RIL & 6.0 & \\
\hline
\end{tabular}




\begin{tabular}{|c|c|c|c|c|c|c|c|}
\hline 6 & qSB-6-1 & $\mathrm{C}$ & Teqing & Lemont & RIL & 5.0 & \\
\hline 6 & qSB-6-2 & RZ508 & Teqing & Lemont & RIL & 7.0 & \\
\hline 7 & qSB-7 & $\mathrm{C} 285$ & Teqing & Lemont & RIL & 5 & \\
\hline 9 & qSB-9 & RZ404 & Teqing & Lemont & RIL & 6.0 & \\
\hline 10 & qSB-10 & RG561 & Teqing & Lemont & RIL & 5.0 & \\
\hline 12 & qSB-12 & G1106 & Teqing & Lemont & RIL & 9.0 & \\
\hline- & Rsb-2(t) & RM 218 & A Mutant & Shuhui 881 & - & - & Xiang et al., 2007 \\
\hline 9 & $\mathrm{qSB}-9^{\mathrm{Tq}}$ & Indel & Teqing & Lemont & $\mathrm{BC}_{1} \mathrm{~F}_{1}$ & - & Zuo et al., 2008 \\
\hline 9 & qShB9-2 & RM245 & Jasmine 85 & Lemont & RIL & 24.3 & Liu et al., 2009 \\
\hline 1 & - & RM1339 & Pecos & Rosemont & $\mathrm{F}_{2}$ & 35 & Sharma et al., 2009 \\
\hline 1 & qSBR1-1 & $\begin{array}{l}\text { Hvssr68-RM306 } \\
\text { (RM1232 } \\
\text {-Hvssr68) }\end{array}$ & Tetep & HP2216 & RIL & $\begin{array}{l}15.01 \\
(8.13)\end{array}$ & $\begin{array}{l}\text { Channamallikarjuna et al., } \\
2010\end{array}$ \\
\hline 3 & qSBR3-1 & RM251-RM338 & Tetep & HP2216 & RIL & 9.96 & \\
\hline 7 & qSRB7-1 & $\begin{array}{l}\text { RM3691-RM336 } \\
\text { (RM5481- } \\
\text { RM3691) }\end{array}$ & Tetep & HP2216 & RIL & $\begin{array}{l}10.02 \\
(26.05)\end{array}$ & $\begin{array}{l}\text { Channamallikarjuna et al., } \\
2010\end{array}$ \\
\hline 8 & qSBR-8-1 & RM210-Hvssr47 & Tetep & HP2216 & RIL & 8.37 & \\
\hline & qSBR9-1 & Hvssr9-27-RM257 & Tetep & HP2216 & RIL & 9.19 & \\
\hline 11 & qSBR11-1 & $\begin{array}{l}\text { Sbq1-RM224 } \\
\text { (Sbq11-RM224) }\end{array}$ & Tetep & HP2216 & RIL & $\begin{array}{l}13.99 \\
(11.99)\end{array}$ & \\
\hline 11 & qSBR11-2 & RM3428-RM209 & Tetep & HP2216 & RIL & 7.81 & \\
\hline 11 & qSBR11-3 & RM536-RM20 & Tetep & HP2216 & RIL & 21.59 & \\
\hline 9 & qShB9-2 & RM 245 & Jasmine 85 & Lemont & RIL & 27.2 & Liu et al., 2013 \\
\hline 9 & qSBR-9 & $\begin{array}{l}\text { Nag08KK18184- } \\
\text { Nag08KK18871 }\end{array}$ & Jarjan & Koshihikari & $\mathrm{BC}_{2} \mathrm{~F}_{3}$ & - & Shiobara et al., 2013 \\
\hline 1 & $q S B 1-1^{H J X 74}$ & ZY7.7-1-5 & Amol3(sona) & HuaJingXian74 & \multirow{2}{*}{$\begin{array}{l}\text { chromosome } \\
\text { segment } \\
\text { substitution lines }\end{array}$} & - & \multirow[t]{2}{*}{ Zhu et al., 2014} \\
\hline 11 & $q S B 11^{H J X 74}$ & ZY27.92-11 & Amol3(sona) & HuaJingXian74 & & - & \\
\hline 7 & qshb7.3 & RM 205 & ARC10531 & BPT-5204 & $\mathrm{BC}_{1} \mathrm{~F}_{2}$ & 21.76 & \multirow[t]{2}{*}{ Yadav et al., 2015} \\
\hline 9 & qshb9.2 & RM 336 & ARC10531 & BPT-5204 & $\mathrm{BC}_{1} \mathrm{~F}_{2}$ & 19.81 & \\
\hline
\end{tabular}


Int.J.Curr.Microbiol.App.Sci (2019) 8(2): 163-175

Fig.1 Symptom of Rice Sheath blight

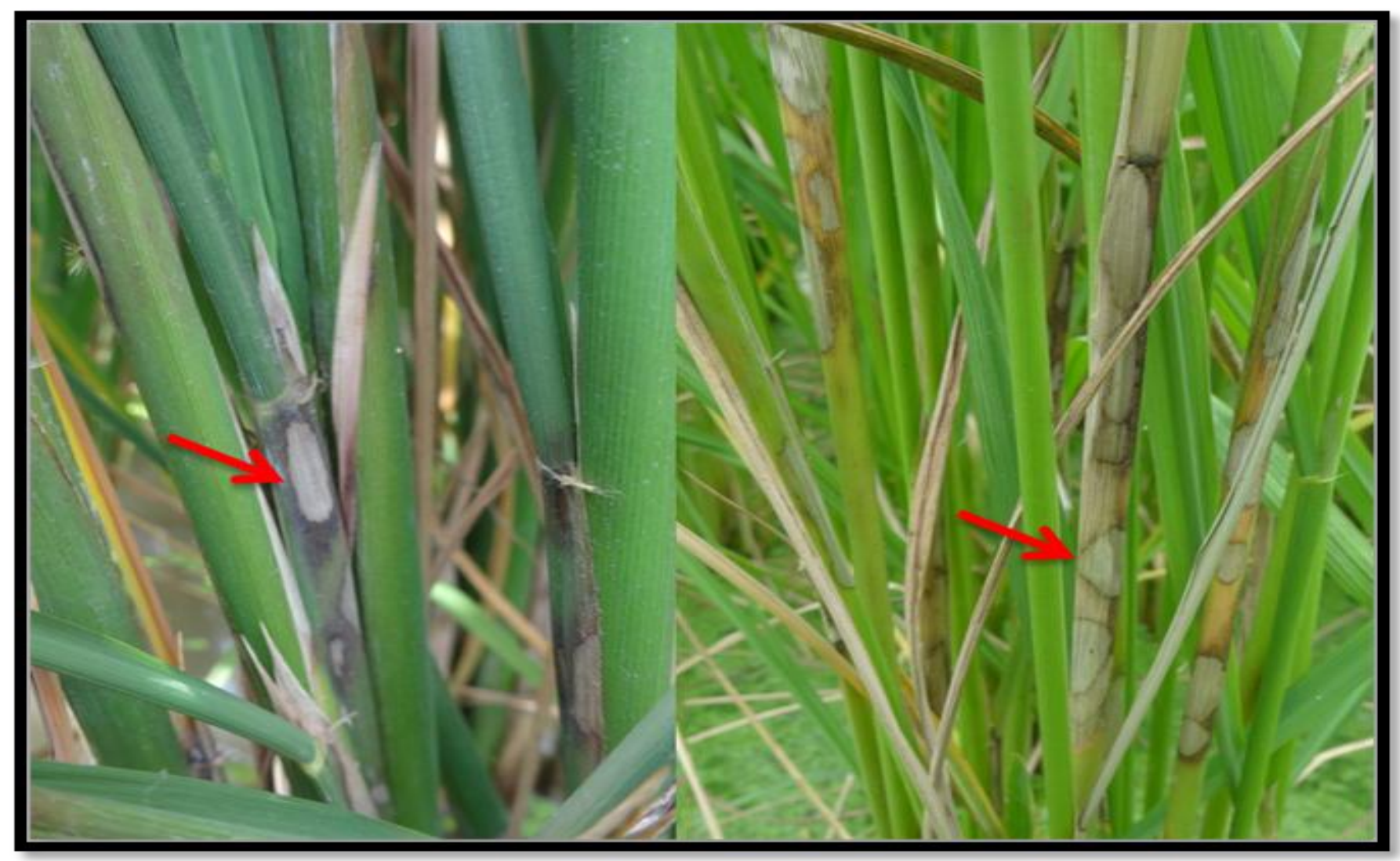


Firstly, genotypes with moderate resistance from the identified pool should be intermated for possible accumulation of several minor effect QTLs that would be evident from enhanced phenotypic effect in populations. Secondly, breeding line with increased resistance to sheath blight than either of it parents should be crossed to an elite susceptible cultivar. Further intermating in segregating populations would ensure retention of accumulated minor effect QTLs in elite background. Modified breeding strategy proposed here coupled with application of advanced genomic tools would widen the scope of development of high yielding elite cultivars with resistance to sheath blight.

\section{References}

Ansari, M. M., Sharma, A. and Thangal, M. H. 1989. Evaluation of rice cultures against sheath blight. Journal of the Andaman Science Association. 5:89-90.

Bhaktavatsalam, G., Satyanarayana, K., Reddy, A. P. K. and John, V.T. 1978. Evaluation of sheath blight resistance in rice. International Rice Research Newsletter. 3:9-10.

Borthakur, B. K. and Addy, S. K. 1988. Screening of rice (Oryza sativa) germplasm for resistance to sheath blight (Rhizoctonia solani). Indian Journal of Agricultural Sciences. 58(7):537-538.

Brooks, S. A. 2007.Sensitivity to a phytotoxin from Rhizoctonia solani correlates with sheath blight susceptibility in rice. Phytopathology. 97: 1207-1212.

Chahal, S. S., Sokhi, S.S. and Ratan, G. S. 2003. Investigation on sheath blight of rice in Punjab. Indian Journal of Phytopathology. 56: 22-26.

Channamallikarjuna, V., Sonah, H., Prasad, M., Rao, G. J. N., Chand, S., Upreti, H. C., Singh, N. K. and Sharma, T. R. 2010. Identification of major quantitative trait loci qSBR11-1 for sheath blight resistance in rice. Molecular Breeding. 25: 155-166.

Che, K. P., Zhan, Q. C., Xing, Q. H., Wang, Z. P., Jin, D. M., He, D. J and Wang, B. 2003. Tagging and mapping of rice sheath blight resistant gene. Theoretical and Applied Genetics, 106: 293-297.

Chen, Z. X., Zhang, Y. F., Feng, F., Feng, M. H., Jiang, W., Ma, Y.Y., Pan, C. H., Hua, H. L., Li, G.S., Pan, X. B., Zuo, S. M. 2014. Improvement of japonica rice resistance to sheath blight by pyramiding qSB $-9^{\mathrm{TQ}}$ and qSB-7 ${ }^{\mathrm{TQ}}$. Field Crops Research. 161: 118-127.

Chen, Z. X., Zou, J.H., Xu, J.Y., Tong, Y. H., Tang, S.Z., Wang, Z. B., Jiang, R.M., Ling, B., Tang, J. and Pan, X.B. 2000. A preliminary study on resources of resistance to rice sheath blight. Chinese Journal of Rice Science. 14: 15-18.

Crill, P., Nuque, F. L., Estrada, B. A. and Bandong, J. M. 1982. The role of varietal resistance in disease management. In: IRRI (ed) Evolution of gene rotation concept for rice blast control. International Rice Research Institute, Los Banos,. 103-121.

$\mathrm{Cu}$, R.M., Mew, T.W., Cassman, K. G. and Teng, P.S. 1996. Effect of sheath blight on yield in tropical, intensive rice production system. Plant Disease. 80:1103-1108.

Das, N. P. 1970. Resistance of some improved varieties of rice (Oryza sativa L.) to sheath blight caused by Rhizoctonia solani Kuhn. Indian Journal of Agricultural Sciences. 40:566-568.

Datta, K., Baisakh, N., Maung Thet, K., Tu, J., Datta, S. K. 2002. Pyramiding transgenes for multiple resistance in rice against bacterial blight, yellow stem borer and sheath blight. Theor Appl Genet. 106:1-8.

Datta, K., Koukolikova, N. Z., Baisakh, N., Oliva, N. and Datta, S. K. 2000. Agrobacterium-mediated engineering for sheath blight resistance of indica rice cultivars from different ecosystems. Theor. appl. Genet. 100: 832-839. 
Datta, K., Velazhahan, R., Oliva, N., Ona, I., Mew, T., Khush, G., Muthukrishnan, S., Datta, S. K. 1999. Over-expression of the cloned rice thaumatin-like protein (PR-5) gene in transgenic rice plants enhances environmental friendly resistance to Rhizoctonia solani causing sheath blight disease. Theor Appl Genet. 98:1138-1145.

Dey, S., Badri J, Prakasam V, Bhadana V. P., Eswari, K. B., Laha, G.S., Priyanka, C., $\mathrm{Aku}, \quad$ R. and Ram, T. 2016. Identification and agro-morphological characterization of rice genotypes resistant to sheath blight. Australasian Plant Pathology. 45:145-153.

Dubey, A. K., Pandian, R. T. P., Rajashekara, H., Singh, V. K., Kumar, G., Sharma, P., Kumar, A., Gopala Krishnan, S., Singh, A. K., Rathour, R. and Singh, U. D. 2014. Phenotyping of improved rice lines and landraces for blast and sheath blight resistance. Indian Journal of Genetics and Plant Breeding. 74(4): 499-501.

Eizenga, G. C., Lee, F. N. and Rutger, J. N. 2002. Screening Oryzae species plant for rice sheath blight resistance. Plant Disease. 86:808-812.

Gokulapulan, C. and Nair, M.C. 1983. Field screening of sheath blight and rice root nematode International Rice Research Newsletter. 8(6):4.

Han, Y.P., Xing, Y.Z., Chen, Z.X., Gu, S.L., Pan, X.B., Chen, X.L. and Zhang, Q.F. 2002. Mapping QTLs for horizontal resistance to sheath blight in an elite rice restorer line, Minghui 63. Acta Genetica Sinica . 29: 565-570.

Hashiba, T., Koike, K., Yuno, I. and Yamada, M. 1982. Model of vertical development of sheath blight lesions on rice plants caused by Rhizoctonia solani Kuhn. Annals of the Phytopathological Society of Japan. 48:499-505.

International Rice Research Institute. Rice Almanac, 3rd Edition. 2002. (Gramene Reference ID 8379).

International Rice Research Institute. Rice
Research and Production in the 21st Century. 2001. (Gramene Reference ID 8380).

Jach, G., Go“rnhardt, B., Mundy, J., Logemann, J., Pinsdorf, E., Leah, R., Schell, J., Maas, C. 1995. Enhanced quantitative resistance against fungal disease by combinatorial expression of different barley antifungal proteins in transgenic tobacco. Plant J. 8: 97-109.

Jia, L., Yan, W., Zhu, C., Agrama, A. H., Jackson, A., Yeater, K., Li, X., Huang, B., $\mathrm{Hu}, \mathrm{B} .$, McClung, A. and $\mathrm{Wu}, \mathrm{D}$. 2012. Allelic Analysis of Sheath Blight Resistance with Association Mapping in Rice. PLoS ONE. 7(3).e32703.

Kalpana, K., Maruthasalam, S., Rajesh, T., Poovannan, K., Kumar, K. K., Kokiladevi, E., Raja, J. A., Sudhakar, D., Velazhahan, R., Samiyappan, R. 2006. Engineering sheath blight resistance in elite indica rice cultivars using genes encoding defense proteins. Plant Sci. 170: 203-215.

Karmakar, S., Molla, K. A., Das, K., Sarkar, S.N, Datta, S. K. and Datta, K. 2017. Dual gene expression cassette is superior than single gene cassette for enhancing sheath blight tolerance in transgenic rice. Scientific Reports. 7: 7900.

Kaur, A., Dhaliwal, L.K. and Pannu, P. P. S. 2015. Role of meteorological parameters on sheath blight of rice under different planting methods. International Journal of Bio-resource and Stress Management. 6(2):214-219.

Kim, J., Jang, I. C., Wu, R., Zuo, W. N., Boston, R. S., Lee, Y. H., Ahn, I. P., Nahm, B. H. 2003. Co-expression of a modified maize ribosome-inactivating protein and a rice basic chitinase gene in transgenic rice plants confers enhanced resistance to sheath blight. Transgenic Res. 12: 475-484.

Kunihiro, Y., Qian, Q., Sato, H., Teng, S., Zeng, D.L., Fujimoto, K and Zhu, L.H. 2002. QTL analysis of sheath blight resistance in rice (Oryza sativa L.). Acta 
Gen Sin. 29:5-15.

Lee, F.N and Rush M.C. 1983. Rice sheath blight: a major rice disease. Plant Disease. 67, 829-32.

Li, Z. K., Pinson, S. R. M., Marchetti, M. A., Stansel, J. W. and Park, W. D. 1995. Characterization of quantitative trait loci (QTLs) in cultivated rice contributing to field resistance to sheath blight (Rhizoctonia solani). Theoretical and Applied Genetics. 91: 382-388.

Liu, G., Jia, Y., Correa-Victoria, F. J., Prado, G. A., Yeater, K. M., McClung, A and Correll, J. C. 2009. Mapping quantitative trait loci responsible for resistance to sheath blight in rice. Phytopathology. 99(9): 1078-1084.

Liu, G., Jia, Y., McClung, A., Oard, J.H., Lee, F.N and Correll, J.C. 2013. Confirming QTLs and finding additional loci responsible for resistance to rice sheath blight disease. Plant Disease. 97:113117.

Manian, S. and Rao, K. M. 1979. Resistance to sheath blight disease in India. International Rice Research Newsletter. 4:5-6.

Marchetti, M. A., Bollich, C. N., McClung, A. M., Scott, J. E. and Webb, B. D. 1995. Registration of RU8703196 diseaseresistant rice germplasm. Crop Science. 35(2):601.

Marchetti, M. A., McClung, A. M., Webb, B.D. and Bollich, C.N. 1996. Registration of B82-761 long-grain rice germplasm resistant to blast and sheath blight. Crop Science. 36(3):815.

Maruthasalam, S., Kalpana, K., Kumar, K. K., Loganathan, M., Poovannan, K., Raja, J. A. J., Kokiladevi, E., Samiyappan, R., Sudhakar, D., Balasubramanian, P. 2007. Pyramiding transgenic resistance in elite indica rice cultivars against the sheath blight and bacterial blight. Plant Cell Reports. 26(6): 791-204.

Ou, S. H. 1985. Rice Disease. Common wealth Agricultural Bureau, Great Britain (UK).

Pan, X. B., Zou, J. H., Chen, Z. X., Lu, J. F.,
Yu, H. X., Li, H. T., Wang, Z. B., Pan. X. Y., Rush, M. C. and Zhu, L. H. 1999. Tagging major quantitative trait loci for sheath blight resistance in a rice variety, Jasmine 85. Chinese Science Bulletin. 44(19): 1783-1789.

Park, D. S., Sayler, R. J., Hong, Y. G., Nam, M. H. and Yang, Y. 2008. A method for inoculation and evaluation of rice sheath blight disease. Plant Disease. 92:25-29.

Peng, H.Y., Zhong, X.Y., Shi-Liangl, G.U., Zong-Xiangl, C., Xue-Biaol, P. and Xiu-Lan, C. 2003. Effect of Morphological Traits on Sheath Blight Resistance in Rice. Acta Botanica Sinica. 45 (7): 825-831.

Pinson, S. R. M., Capdevielle, F. M. and Oard, J. H. 2005. Confirming QTLs and finding additional loci conditioning sheath blight resistance in rice using recombinant inbred lines. Crop Science. 45: 503-510.

Pinson, S. R. M., Oard, J. H., Groth, D., Miller, R., Marchetti, M. A., Shank, A. R., Jia, M. H., Jia, Y., Fjellstrom, R.G. and Li, Z. 2008. Registration of TIL:455, TIL:514, and TIL:642, Three rice germplasm lines containing introgressed sheath blight resistance alleles. Journal of Plant Registration. 2(3):251-254.

Rajan, K. M. and Nair, P.V. 1979. Reaction of certain rice varieties to sheath blight and sheath rot diseases. Agricultural Research Journal of Kerala (India). 17:259-260.

Rajesh, T., Maruthasalam, S., Kalpana, K., Poovannan, K., Kumar, K. K., Kokiladevi, E., Sudhakar, D. Samiyappan, R. and Balasubramanian, P. 2016. Stability of sheath blight resistance in transgenic ASD16 rice lines expressing a rice chil1 gene encoding chitinase. Biologia Plantarum. 60 (4): 749-756.

Rao, K. M. 1995. Sheath blight disease of Rice. Delhi: Daya Publishing House.

Roy, A.K. 1977. Screening of rice cultures against sheath blight. Indian Journal of Agricultural Sciences. 47(5):259-260. 
Sato, H., Ideta, O., Ando, I., Kunihiro, Y., Hirabayashi, H. and Iwano, M. 2004. Mapping QTLs for sheath blight resistance in the rice line WSS2. Breeding Science. 54: 265-271.

Sattari, A., Fakheri, B., Noroozi, M. and Gudarzi, K. M. 2014. Review: Breeding for Resistance to Sheath blight in rice. Intl J Farm \& Alli Sci. 3 (9): 970-979.

Savary, S., Castilla, N.P., Elazegui, F.A., McLaren, C. G., Ynalvez, M. A. and Teng, P. S. 1995. Direct and indirect effects of nitrogen supply and disease source structure on rice sheath blight spread. Phytopathology. 85:959-965.

Sha, X. Y. and Zhu, L. H. 1990. Resistance of some rice varieties to sheath blight (ShB). International Rice Research Newsletter. 15:7-8.

Shah, J. M., Raghupathy, V., Veluthambi, K. 2009. Enhanced sheath blight resistance in transgenic rice expressing an endochitinase gene from Trichoderma virens. Biotechnol. Lett. 31: 239.

Sharma, A., McClung, A. M., Pinson, S. R. M., Kepiro, J. L., Shank, A. R., Tabien, R.E., Fjellstrom, R. 2009. Genetic mapping of sheath blight resistance QTLs within tropical japonica rice cultivars. Crop Science. 49: 256-264.

Shiobara, F.T., Ozaki, H., Sato, H., Maeda, H., Kojima, Y., Ebitani, T. and Yano, M. 2013. Mapping and validation of QTLs for rice sheath blight resistance. Breeding Science. 63: 301-308.

Singh, A., Singh, V. K., Singh, S. P., Pandian, R. T. P., Ellur, R. K., Singh, D., Bhowmick, P. K., Gopala Krishnan, S., Nagarajan, M., Vinod, K. K., Singh, U. D., Prabhu, K. V., Sharma, T. R., Mohapatra, T., Singh, A. K. 2012. Molecular breeding for the development of multiple disease resistance in Basmati rice. $A o B$ PLANTS. pls029; doi:10.1093/aobpla/pls029.

Singh, R. and Dodan, D. S. 1995. Reactions of rice genotypes to bacterial leaf blight, stem rot, and sheath blight in Haryana. Indian Society of Mycology and Plant
Pathology. 25:224-227.

Singha, K. D. and Borah, P. 2000. Screening of local upland cultivars of Assam against sheath blight. Annals of Biology. 16:161-162.

Slaton, N. A., Cartwright, R. D., Meng, J., Gbur, E. E. Jr and Norman, R. J. 2002. Sheath blight severity and rice yield as affected by nitrogen fertilizer rate, application method, and fungicide. Agronomy Journal. 95:1489-1496.

Sridevi, G, Parameswari, C., Sabapathi, N., Raghupathy, V., Veluthambi, K. 2008. Combined expression of chitinase and b-1, 3-glucanase genes in indica rice (Oryza sativa L.) enhances resistance against Rhizoctonia solani. Plant Sci. 175:283-290.

Tang, Q., Peng, S., Buresh, R.J., Zou, Y., Castilla, N. P., Mew, T.W. and Zhong, X. 2007. Rice varietal difference in sheath blight development and its association with yield loss at different levels of $\mathrm{N}$ fertilization. Field Crops Research. 102: 219-227.

Webster, R. K. and Gunnell P.S. 1992. Compendium of Rice Diseases. American Phytopathological society, St Paul, MN, USA.

Willocquet, L., Fernandez, L. and Savary, S. 2000. Effect of various crop establishment methods practiced by Asian farmers on epidemics of rice sheath blight caused by Rhizoctonia solani. Plant Pathology. 49:346-354.

Willocquet, L., Noel, M., Hamilton, R.S. and Savary, S. 2010. Susceptibility of rice to sheath blight: an assessment of the diversity of rice germplasm according to genetic groups and morphological traits. Euphytica. DOI 10.1007/s10681-0110451-9.

Wu Y. L. 1971. Varietal differences in sheath blight resistance of rice obtained in Southern Taiwan. SABRAO Newsletter. $3: 5$

Xiang, X.C., Li, J.H., Zhang, K.Z., Zhao, P., Li, P. 2007. Genetic analysis of a rice mutant with resistance to sheath blight 
and its preliminary gene mapping. Journal of Southwest University: Science \& Technology. 22(2): 76-81.

Xie, Q. J., Linscombe, S. D., Rush, M. C. and Jodarikarimi, F. 1992. Registration of LSBR-33 and LSBR-5 sheath blight resistant germplasm lines of rice. Crop Science. 32(2):507.

Xu, Q., Yuan, X. P., Yu, H. Y., Wang, Y., Tang, S. X. and Wei, X. H. 2011. Mapping quantitative trait loci for sheath blight resistance in rice using double haploid population. Plant Breeding. 130: 404-406.

Yadav, S., Anuradha, G., Kumar, R. R., Vemireddy, L. R., Sudhakar, R., Donempudi, K., Venkata, D., Jabeen, F., Narasimhan, Y. K, Marathi, B. and Siddiq, E. A. 2015. Identification of QTLs and possible candidate genes conferring sheath blight resistance in rice (Oryza sativa L.). SpringerPlus. 4:175.

Zhu, Y., Zuo, S., Chen, Z., Chen, X., Li, G., Zhang, Y., Zhang, G. and Pan, X. 2014. Identification of two major rice sheath blight resistance QTLs, qSB1-1 ${ }^{\mathrm{HJX} 74}$ and $\mathrm{qSB} 11^{\mathrm{HJX} 74}$, in field trials using chromosome segment substitution lines. Plant Dis. 98:1112-1121.

Zou, J. H., Pan, Z. X., Chen, Z. X., Xu, J. Y., Lu, J. F., Zhai, W. X. and Zhu, L. H. 2000. Mapping quantitative trait loci controlling sheath blight resistance in two rice cultivars (Oryza sativa L.). Theoretical and Applied Genetics. 101: 569-573.

Zuo, S., Zhang, L., Wang, H., Yin, Y. and Zhang, Y. 2008. Prospect of the QTL qSB- $9^{\mathrm{Tq}}$ utilized in molecular breeding program of japonica rice against sheath blight. Journal of Genetics and Genomics. 35: 499-505.

Zuo, S., Zhang, Y., Chen, Z., Jiang, W., Feng, M., Pan, X. 2014.Improvement of rice resistance to sheath blight by pyramiding QTLs conditioning disease resistance and tiller angle.2014. Rice Sci. 21(6):318-326.

\section{How to cite this article:}

Susmita Dey, Jyothi Badri, Khushi Ram, A.K. Chhabra and Janghel, D.K. 2019. Current Status of Rice Breeding for Sheath Blight Resistance. Int.J.Curr.Microbiol.App.Sci. 8(02): 163-175. doi: https://doi.org/10.20546/ijcmas.2019.802.020 